\title{
The Rise of MSME (Micro, Small, and Medium Enterprises): A Critical Review from Contributive Perspective in Improving Human Development Index (HDI)
}

\author{
Mashudi $^{1}$, Kholidin $^{2}$, Anafil Windriya ${ }^{3}$, Stacia Reviany Mege ${ }^{4}$ \\ \{emashud_bli@yahoo.co.id ${ }^{1}$, vokasikholidin@gmail.com ${ }^{2}$, anafilwindriya@gmail.com ${ }^{3}$, \\ staciareviany@live.undip.ac.id $\left.{ }^{4}\right\}$ \\ Universitas Diponegoro, Indonesia ${ }^{1,2,3,4}$
}

\begin{abstract}
Departing from the issue of the high number of MSMEs and the low number of Human Development Index (HDI), this study aims at investigating the development of MSMEs, the supporting factors and the obstacles in the MSME development, as well asits contribution to the escalation of HDI score. This research is a qualitative descriptive study. The informants in this study are determined purposively consisting of actors and stakeholders in the management of MSME and the development of the HDI score. Data collection techniques were focus group discussions and were reinforced with interviews, observations, and documentation. The results revealed that the number of MSME increases, the labor absorption increases, and the production volume increases. However, such findings also inhibit the increase of the HDI score due to investors who do not support the economic development of MSME actors.
\end{abstract}

Keywords: MSME, Human Development Index (HDI)

\section{Introduction}

The current development paradigm is economic growth which is measured from human development in terms of the human life quality in each country. One measure used to examine human life quality is the Human Development Index (HDI), the indicators of which include the education level, health quality, and economic level or purchasing power. Through the improvement of the three indicators, human life quality is expected to improve. This is due to the heterogeneity of individuals, geographical differences, and various social conditions of the society. Therefore, income is no longer the main benchmark in calculating the success rate of development. However, the success of human development cannot be separated from the performance of the government who are responsible for creating regulations for achieving social welfare.

For almost two decades, HDI has continued to be utilized in various development plans. As science and technology develop and development challenges, UNDP develops new ideas in development calculation. In 2010, UNDP formally introduced the HDI calculation using the new method which employs new indicators. The indicators of literacy rate and gross participation rate are replaced by expected years of schooling and mean years of schooling. The indicator of Gross Domestic Product (GDP) per capita is also replaced by the Gross National 
Product (GNP) per capita. In addition, the calculation of the average index is also changed from an arithmetic average to geometrics.

Indonesia began applying the HDI calculation using the new method in 2014. Since then, Indonesia has never used the old method. The indicators used in Indonesia are the same as UNDP, except for the GNP per capita. This indicator is represented by per capita expenditure. To maintain the continuity of the calculation, the new HDI calculation method is calculated from 2010 to 2014 at the district/city level. The new method of calculating HDI turns out to have an impact that must be examined to avoid misinterpretation. This new method causes the HDI level to be lower than the previous method. Besides, this method causes a change in ranking in some areas. However, due to methodological differences, the ranking generated by the new method cannot be compared to those generated by the old method as can be seen in Figure 1 .

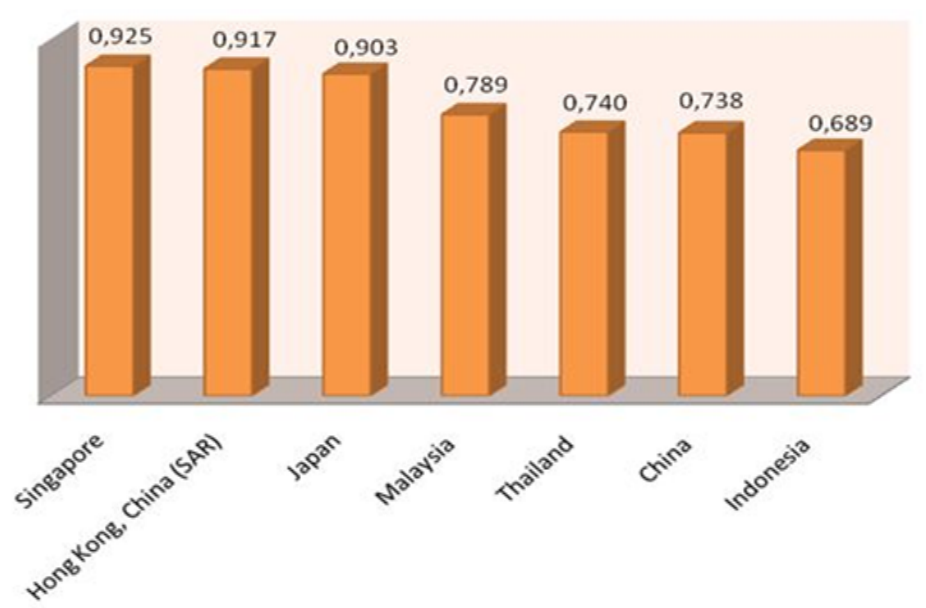

Fig. 1. Human Development Index in Asia Pacific Countries, 2016.

According to the report of UNDP (United Nations Development Program) in 2016 on theHuman Development Index (HDI), Indonesia's rankings of achievement in education in 2015 was reported at the $113^{\text {th }}$ place of 188 countries which was lower than some countries in Asia Pacific such as Singapore, Hong Kong, Japan, Malaysia, Thailand, and China.

In Figure 1, it can be seen that the Human Development Index of Indonesia in 2015 was the lowest compared to five other countries in Asia pacific. Indonesia is at $113^{\text {th }}$ place with a score of 0.689. While the highest HDI was obtained by Singapore with a score of 0.925 , the fifth rank out of 188 countries. The low HDI shows low global competitiveness. The low HDI in Indonesia is due to the three indicators that present the success of education, health, and a decent standard of living that have not been accomplished in every province in Indonesia today. This can be seen from the graphic image that shows the Human Development Index in six provinces in Java, which is the most populous island in Indonesia. 
Human Development Index in Java

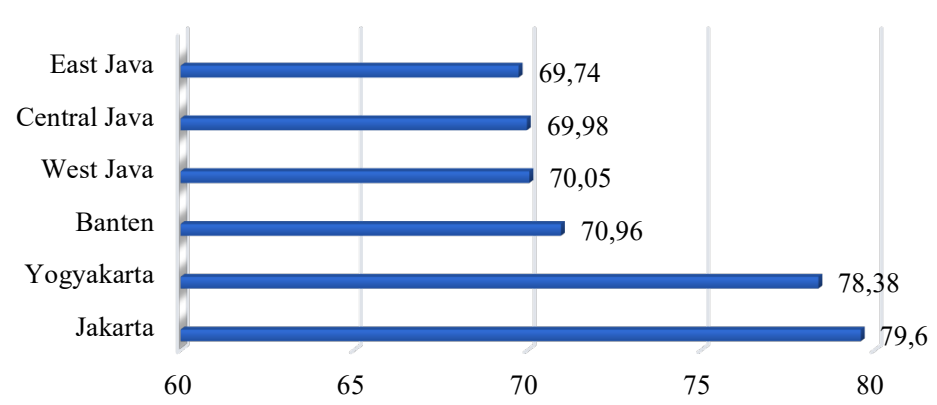

Fig. 2. Human Development Index in Java (National Statistics Indonesia, 2016).

From the data in Figure 2, it can be seen that currently, the lowest Human Development Index is in the area of East Java Province with a percentage of $69.74 \%$ followed by Central Java Province with $69.98 \%$. Meanwhile, the province with the highest HDI is DKI Jakarta with a percentage of $79.6 \%$. The low HDI in Central Java is being greatly influenced by the results of $\mathrm{HDI}$ at the district/city level which is represented in Figure 3.

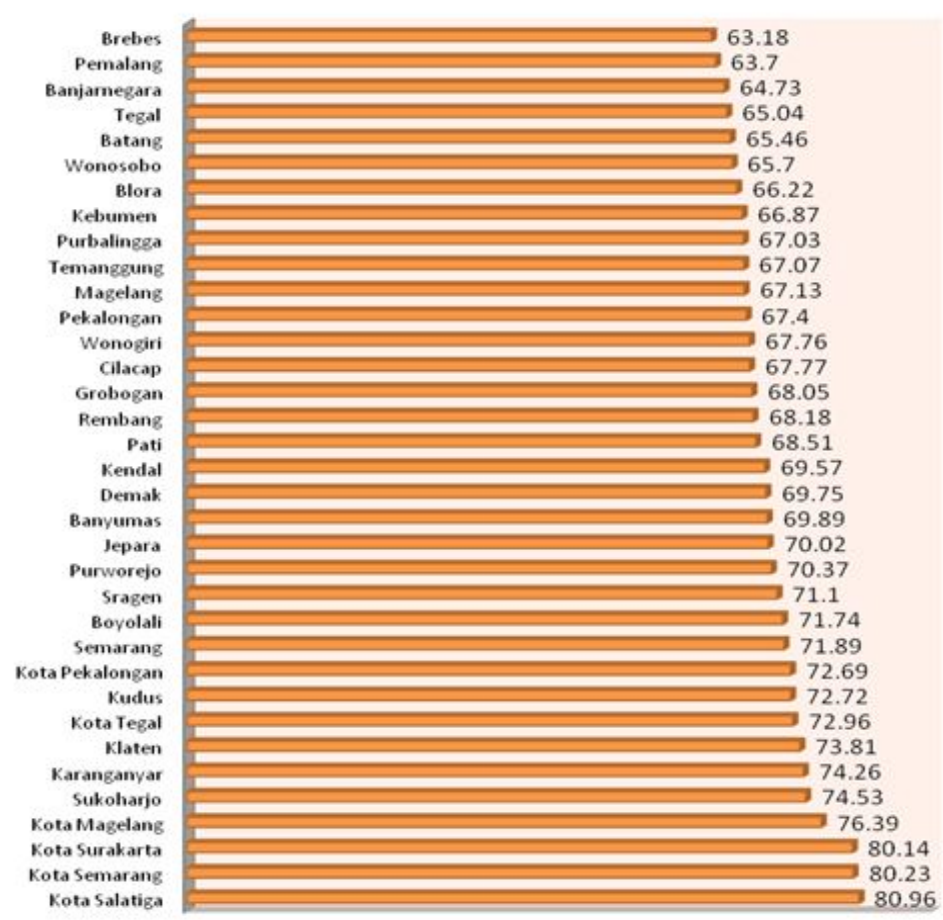

Fig. 3. Human Development Index of Regency/City in Central Java Province (Central Java in Numbers, 2016). 
From Figure 3, it can be seen that the lowest Human Development Index of Regencies/Cities in Central Java Province is Brebes Regency with an index of 63.18 followed by Pemalang Regency with an index of 63.7. Banjarnegara Regency has the third-lowest HDI with an index of 64.73. The low HDI in Pemalang Regency is assumed due to 3 (three) basic dimensions used to measure HDI, namely health represented by Life Expectancy at birth, education represented by Expected Years of Schooling and Mean Years of Schooling, and a decent standard of living represented by spending or purchasing power that are still low. This fact can be seen in Figure 1.4 below. Longer life is everyone's dream, therefore, better health is needed to achieve that. Human development broadens human choices by requiring a long life. Prolonged and healthy life proxies used in human development are indicators of life expectancy at birth (e0). These indicators are an indicator of public health.

Education expands one's opportunities and enhances creativity and imagination. As an added value, education will also broaden other options. Educated humans will pay more attention to health rates to live longer. Besides, educated people will also have a great chance of getting a more decent job and income. Hence, education becomes important as a means to improve human beings' quality to have more opportunities. Expenditures or income have given a litter picture of the size of the development, as it did in the era of 70s. However, money has an important meaning to expand choices, especially for the poor. Thus, the development of the expenditure level becomes interesting to be researched.

\section{IPM}

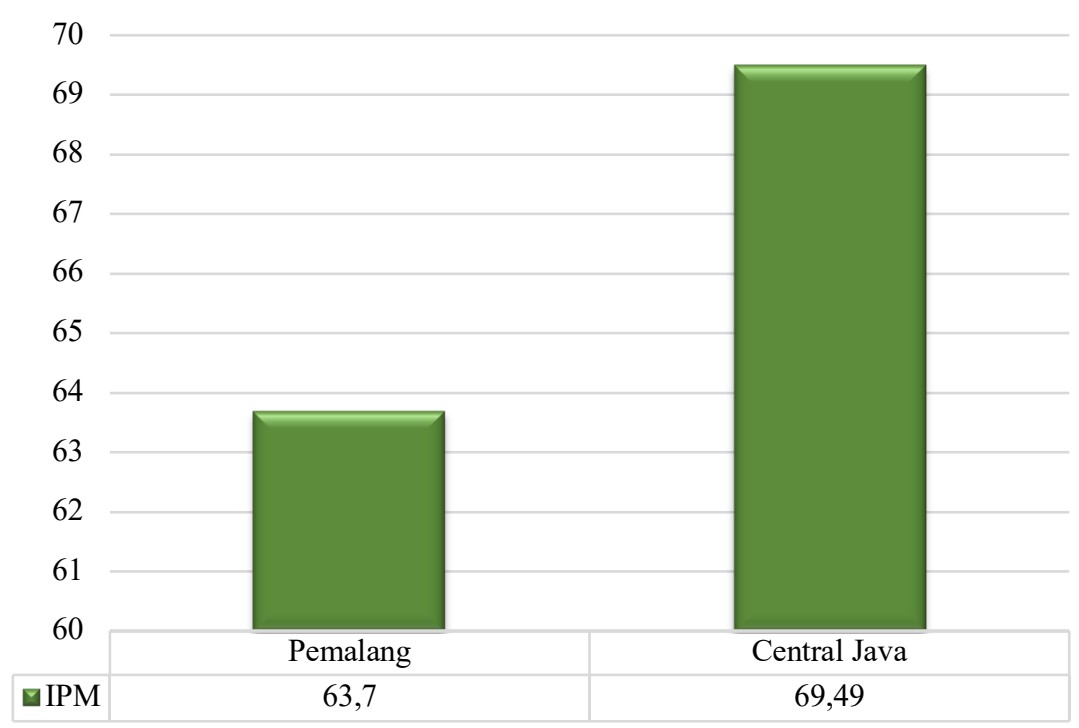

Fig. 4. Comparison of HDI Achievement between Pemalang Regency and Central Java Province (Central Java in Numbers, 2016).

From Figure 4, it can be seen that currently, the Human Development Index in Pemalang Regency (63.7) has not been able to align or exceed the achievement of the Human Development Index in the Central Java Province (69.49). 


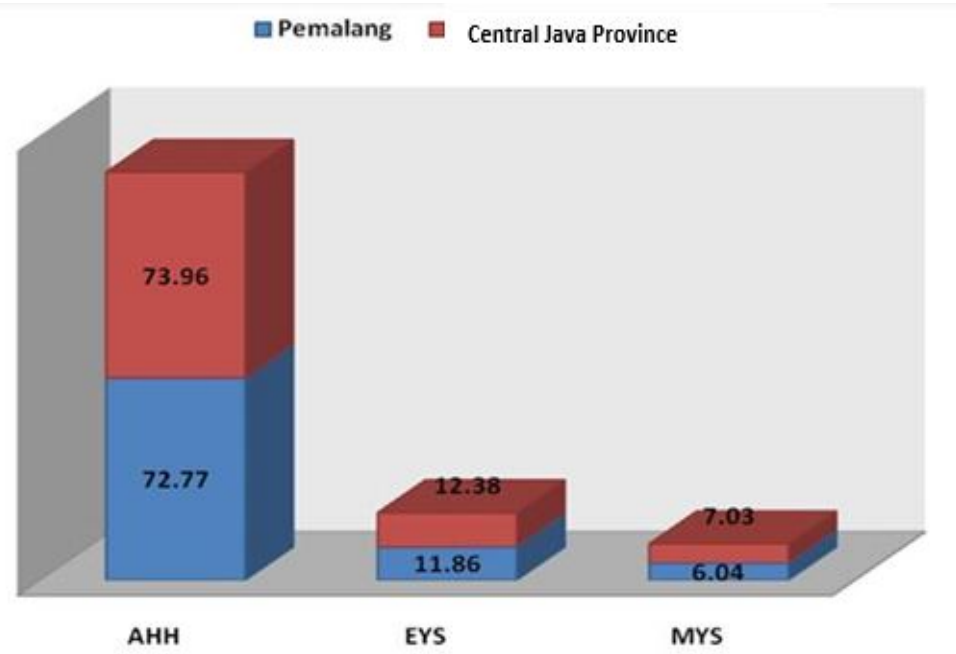

Fig. 5. Indicators of Human Development Index in Pemalang Regency and Central Java Province (Central Java in Numbers, 2016).

According to Figure 5, currently, the overall achievement of Life Expectancy, Expected Years of Schooling, Mean Years of Schooling in Pemalang Regency is still below average and cannot exceed the achievement of Central Java Province. The Life Expectancy in Pemalang Regency is 72.77, while in Central Java, the Life Expectancy has reached 73.96. The Expected Years of Schooling in Pemalang Regency is 11.86 while in central Java Province has reached 12.38. In terms of Mean Years of Schooling, Pemalang Regency is at 6.04 which is still very low, while Central Java Regency has reached 7.03. This low achievement of Life Expectancy at birth, Expected Years of Schooling, and Mean Years of Schooling in Pemalang Regency is also followed by the low standard of decent living compared to Banjarnegara and Brebes Regency.

\section{Decent Standard of Living in Pemalang, Banjarnegara, Brebes Regency, and Central Java Province}

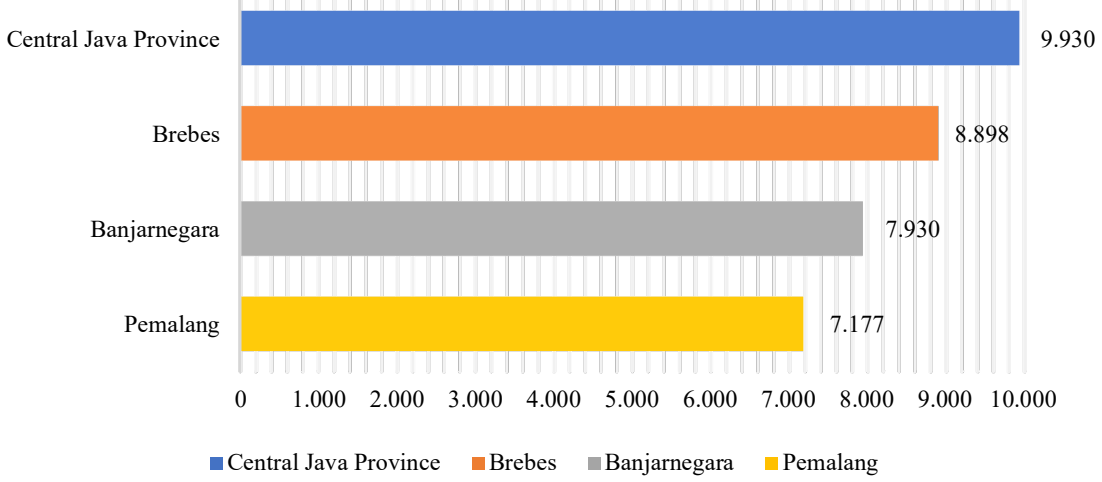

Fig. 6. Decent Standard of Living in Pemalang, Banjarnegara, Brebes Regency, and Central Java Province (Central Java in Numbers, 2016). 
Another indicator of HDI is the economic level or purchasing power. Society will have purchasing power if they have an income that is obtained from their occupation. Therefore, the presence of SMEs is one of the opportunities for society to earn income. The society can be involved in MSMEs, both as managers and as workers. In Pemalang Regency, there are 12,667 units of small-sized businesses and 95 units of medium-sized businesses. Thus, the number of small and medium-sized businesses is 12,752 units which absorbed the labour of 44,764 workers.

Based on the background that describes low HDI and high number of MSMEs as well as the amount of labour absorption, this study aims to determine the growth of MSMEs and labour absorption, growth in production volume, and the contribution of MSMEs in increasing HDI.

\section{Research Methods}

This study used a qualitative research method. The characteristic of qualitative research is that the data are stated in a state of fairness or as it is (natural setting) by not being represented in the form of symbols or numbers, whereas research basically means a series of activities or processes of revealing the secret of something unknown by using systematic, directed, and accountable methods [1].

The informants in this study were the actors and stakeholders for the HDI improvement, including 1) Government: All relevant SKPD staff in Pemalang Government, namely the Education Office, BAPPEKAB, Health Office, and Department of Industry; 2) Private Sector: entrepreneurs in Pemalang Regency; and 3) MSME Observers determined purposively. The data were obtained using documentation, interview, and observation techniques. The data were then analysed using a descriptive qualitative analysis design.

The data validity is: "the degree of trust or truth of the research results as a standard in qualitative research" [2]. As a qualitative study, a standard to see the degree of trust or truth of the research results is required. In qualitative research, the standard is often referred to as the data validity. Lincoln and Guba [3] suggested that there are 4 criteria used to check the data validity, namely credibility, transferability, dependability, and confirmability.

\section{Results and Discussion}

\subsection{Human Development Concept}

Human Development, according to UNDP, is defined as a process aimed at broadening choices for people. In this concept, people as the ultimate end and the development effort as the principal means to achieve that goal.

The human development paradigm sees that efforts to improve human quality have intrinsic value, in a sense, as an end in themselves. This perspective is different from human resource development which places people as sources or inputs of development and sees human quality as a means to generate income. As a holistic development paradigm, human development views development programs that are designed should be characterized as "of, for and by people". These characteristics are described as follows: first, of people, namely the empowerment of the people through investments in the field of health, education, and other basic social services; 
second, for people, namely the empowerment of the people through the creation of employment opportunities and expansion of business opportunities by expanding the economic activities of a region; third, by people, namely the empowerment of the people which can increase their dignity through participation in decision making in all fields. In this case, it means that it involves decisions in the development process.

The concept of human development in the above description is far broader than conventional economic development theories including the models of economic growth, human resource development (HR), welfare approach, and basic human needs approach. The models of economic growth are related to increasing GNP. Human resource development places humans primarily as inputs of the production process (as a means, not an end). The welfare approach sees humans as beneficiaries, not as agents of change in development. The basic needs approach focuses on the supply of goods and services for life necessities.

However, economic development or more precisely economic growth is a prerequisite for the achievement of human development because economic development will increase productivity and income through creating employment opportunities. According to UNDP, the relationship between economic growth and economic development is reciprocal which means that economic growth affects human development. Therefore, it is difficult to imagine a country or region that can carry out sustainable economic development without adequate economic growth.

The relationship between economic growth and human development is empirically proved not to be automatic. This means that many countries or regions experience rapid economic growth without being followed by balanced human development. On the contrary, many countries experience moderate economic growth but they are able to impressively improve the performance of human development. This empirical evidence does not necessarily mean that economic growth is not important for human development. In fact, economic growth is the main means for human development, especially economic growth that is evenly sectoral and conducive to the creation of employment opportunities. This non-automatic relationship is a challenge for government executors to design sound policies so that the relations between the two are mutually reinforcing, especially in the current regional autonomy era.

The relationship between economic growth and human development happens through two kinds of paths. The first path is through government policy and expenditure [4]. In this case, the factors that determine priorities are basic education and health. The amount of expenditure indicates the government's commitment to human development. In this case, the determining factor is the amount and composition of household expenditure for basic needs such as the nutrition fulfilment of its members, the cost of health services and basic education, and other similar activities.

In addition to government and household expenditures, the relationship between the two variables occurs through job creation. This aspect is very important because, in fact, job creation is the "main bridge" that connects the two [5]. Through human development efforts, the basic abilities and skills of the labour will increase. Besides, human development will affect the type of domestic production, research activities and technological development, which will ultimately affect the composition of output and exports of a country or region. The strong mutual relationship between human growth and development is also influenced by government institutional factors, the distribution of private and social resources and social capital.

The role of the government institutional factor is clear because its very existence determines the implementation of public policy [6][7]. The resource distribution factor is also clear because, without equitable resource distribution (for example, inland tenure or other economic 
resources), it will only cause society frustration. The social capital factor emphasizes the important role of community participation in the process of public policy making [8][9].

Through a deep understanding of the concept of human development, development planners need to look at all the problems and needs of development comprehensively. Therefore, they can formulate the right policies to carry out human development in the regions. The right policies in human development can be arranged from the analysis process of human development to its implications for intervention strategies and the needs of the program with a human development perspective.

Following the global concept of human development as described above, human development policies can be described as follows:

a) Improve productivity

People need to increase their ability to be able to creatively and independently create jobs, and/or sources of income that enable them to have a decent living. The government, in this case, can create a conducive climate to support these efforts. In this regard, education (formal and non-formal) and health are important aspects that need priority.

b) Improve equity

To increase this productivity capability, everyone must have equal opportunities and access to all available economic and social resources. Various development policies with a human development perspective are always oriented toward equity and should not be discriminatory. Everyone strives to obtain equal opportunity and access proportionally. Various facilities (access) must be created, both economic and social, for everyone. In this case, all obstacles that minimize the opportunities to gain access must be removed so that people can take advantage of the opportunities available and participate in activities that improve life quality.

c) Improve sustainability

Providing access to economic and social resources must be ensured not only for the current generation but also for the future generation. All resources (physical, human, and environmental) must not be used up or damaged, but must always be recovered. Future development policies give priority to efforts to apply the concept of environmentally sound development appropriately and broadly.

d) Improve empowerment

Society must be involved in decision making and the processes that will determine their lives. Society must be allowed to take advantage of the development process. Therefore, development must be "by" society and not just "for" society. In this case, human development policies must always be directed toward Fefforts to encourage, find, and recognize their problems, overcome the problems themselves, and for themselves within their limits. Future policies, in human development, must be directed at the process of social empowerment.

\subsection{Micro, Small, and Medium Enterprises}

Micro, small, and medium enterprises (MSMEs) are independent productive business units, carried out by individuals or business entities in all economic sectors. In principle, the distinction between micro-enterprises (ME), small enterprises (SE), and large enterprises (LE) is generally based on the value of the initial assets (excluding land and buildings), average annual turnover, or the number of permanent workers. In general, ME employs five (5) or fewer permanent workers, while small and medium enterprises (SMEs) employ less than 100 workers. 
In Indonesia, the definition of MSME is regulated in the Law of the Republic of Indonesia Number 20 of 2008 concerning MSME. In Chapter I (General Provisions), Article 1 states that $\mathrm{ME}$ is a productive business owned by individuals and/or individual business entities that meet the ME criteria as regulated in the Act. SE is a productive economy that stands alone, which is carried out by individuals or business entities that are not subsidiaries or branch companies that are owned, controlled, or become a part either directly or indirectly of the medium or large enterprise.

Most micro entrepreneurs in Indonesia have an economic background, in other words, the main reason for carrying the business is to get improved income. This shows that micro entrepreneurs take the initiative to get income to meets the family daily needs. In addition, being a micro entrepreneur is also due to a heredity factor to continue the family business. It appears that family factors are still dominant in choosing the type of business, for example, if parents work as farmers, their children will become farmers, if parents are sarong craftsmen, the children will become sarong craftsmen too, and so on.

The background of small-scale entrepreneurs is more varied compared to micro enterprises. Although the economic background is also the main reason, some others have more realistic reasons by looking at business opportunities going forward even with limited capital. Most small entrepreneurs in Indonesia have a business reason because there is a business opportunity and a large market share. There are also a number of small entrepreneurs who are doing business because of inheritance or descent and motivation to provide expertise and create employment opportunities for local people. However, a number of small entrepreneurs have other reasons for doing business, such as do not have opportunities in various fields due to low level of formal education or physical conditions.

The world has recognized MSMEs in playing a very vital role in development and economic growth, not only in developing countries but also in developed countries. In developed countries, MSMEs have a very important role because compared to large businesses, MSMEs absorb the most labour and their contribution to the formation of GDP is greater.

\subsection{Discussion}

The contribution of MSMEs to the HDI improvement can be seen in the results of interviews with several informants and data from several documents which were gathered, as follows:

From the results of the study, it can be seen that the Human Development Index in Pemalang Regency until 2016 showed a significant increase in realization. During 2011-2016, there was an HDI increase of 4.51 points in 2016 resulting in HDI of 64.17 as in the following table.

Table 1. Development of the Human Development Index

\begin{tabular}{|l|c|c|c|c|c|c|}
\hline \multicolumn{1}{|c|}{ Indicators } & 2011 & 2012 & 2013 & 2014 & 2015 & 2016 \\
\hline Life Expectancy (Th) & 72.37 & 72.48 & 72.59 & 72.64 & 72.77 & 72.87 \\
\hline Expected Years of Schooling (Th) & 10.45 & 10.64 & 11.05 & 11.26 & 11.86 & 11.87 \\
\hline Mean Years of Schooling (Th) & 5.19 & 5.51 & 5.72 & 5.87 & 6.04 & 6.05 \\
\hline Adjusted Per Capita Expenditure (Rp.000) & 6.488 & 6.725 & 6.863 & 6.911 & 7.177 & 7.447 \\
\hline IPM & $\mathbf{5 9 . 6 6}$ & $\mathbf{6 0 . 7 8}$ & $\mathbf{6 1 . 8 1}$ & $\mathbf{6 2 . 3 5}$ & $\mathbf{6 3 . 7 0}$ & $\mathbf{6 4 . 1 7}$ \\
\hline
\end{tabular}

Source: BPS (Statistic Indonesia) Pemalang Regency.

Although the HDI in Pemalang Regency continues to increase every year, the achievement of the HDI is not optimal. Compared to other Regencies/Cities in Central Java Province, HDI of Pemalang Regency is $34^{\text {th }}$ out of 35 Regencies/Cities. This condition is a concern for the 
government to pay more attention to the process of human development. Especially with the existence of Pemalang Regency Regulation Number 12 of 2016 concerning the Medium-term Development Plan of Pemalang Regency in 2016-2021. Certainly, from the reference to the regional regulation, regional governments should be able to prioritize development including infrastructure, facilities, education, health, and income/purchasing power as composite indicators forming the Human Development Index.

Meanwhile, the potential of Pemalang Regency to support the Human Development Index (HDI) improvement is also possible considering that Pemalang Regency has abundant natural resources such as agriculture, plantations, fisheries, industry, services, and trade. The results of these economic activities should be able to contribute substantial added value to the regional economy and the welfare of the people in Pemalang Regency.

Data on the potential of Pemalang Regency which supports the increase in HDI is corroborated by the view of Bapak Priya (Head of Trade in the Department of Industry and Trade of Pemalang Regency). He stated:

"The products of agriculture, plantation, and fishery in Pemalang Regency are pretty good. In addition to being able to meet the needs in the regency itself, agricultural, plantation, and fishery products are distributed to cities around Pemalang. Besides, there are additional supplies from other areas including products of agriculture, plantation, and fishery which only stop by or transit in Pemalang and then distributed to cities around Pemalang. Likewise, besides being circulated in Pemalang and its surroundings, imported fruit is also circulated to other cities outside Java" (Interview on 29 July 2019).

Through interview with and documentation from the Department of Industry and Trade, the following data were also obtained: the realization of non-oil and gas exports, especially handicrafts of Goyor Sarong totalling 23,240 pieces for US\$331,754; boxer shorts totalling $7,705,407$ pieces for US\$14,744,816; blazer/shirts totalling 161,500 pieces for US\$892,708; and eyelashes totalling $3,462,480$ pieces/packs for US $\$ 2,596,803$.

In addition, the following information was also obtained: the total population of Pemalang Regency is 1,292,573 people; 41,424 workers are absorbed by 12,667 small industries; 95 medium industries absorb 3,340 workers; and 2 large industries absorb 1,348 workers. The status of the job seekers are 14,441 people with 8,874 people are absorbed, in details, 6,983 people $(72.58 \%)$ are absorbed in the MSMEs and the other 1,891 job seekers are absorbed in other sectors, while 5,567 prospective workers or 38\% have not been accommodated.

By observing the data mentioned above, it can be stated that MSMEs and large industries have not been able to absorb all the job seekers. Thus, the number of job seekers who have not been accommodated is still quite high, which is 5,567 job seekers or $38 \%$ of the overall job seekers. As a result, these $38 \%$ of job seekers are unemployed for a while, do not have income, and become a burden on their family which then results in low income per capita and purchasing power. Hence, the researchers can put forward the hypothesis that the large number of employment will have an impact on low per capita income and subsequently low purchasing power so it will not be strong enough to improve HDI.

The data were also obtained through interview with MSME actors that Pemalang Regency has 12,752 units MSMEs, which is a quite large number, but were not enough to improve the welfare of the people because most of them were controlled and capitalized by middlemen and they had to sell their products to middlemen at prices determined by middlemen. Therefore, the 
MSMEs are not independent and the profits obtained are not as big as selling their products to other than the middleman.

\section{Conclusion}

Judging from the number of units, production volume, export value, and absorption of job seekers, MSMEs in Pemalang Regency are quite potential, but are not enough to help improve HDI because middlemen still play a dominant role that reduces the independence and purchasing power of MSMEs.

The district government should take action to control the middlemen who control and capitalize MSME actors by providing enlightenment on the importance of independence. At the same time, the government provides capital for MSME actors to avoid further control of middlemen.

\section{References}

[1] M. B. Miles, A. M. Huberman, and J. Saldaña, "Qualitative data analysis: A methods sourcebook. 3rd," ed Thousand Oaks, CA Sage, 2014.

[2] L. J. Moleong, Metodologi Penelitian Kualitatif. Bandung: PT. Remaja Rosdakarya, 2010.

[3] Y. S. Lincoln and E. G. Guba, "Naturalistic observation," Thousand Oaks, CA, 1985.

[4] L. Agustino, Politik dan Kebijakan Publik. 2006.

[5] UNDP, Humant Development Report. New York: Oxford University Press, 2000.

[6] T. R. Dye and T. R. Dye, Understanding public policy. Prentice Hall Englewood Cliffs, NJ, 1992.

[7] P. Santoso, "Modul Pembelajaran Analisis Kebijakan Publik," Yogyakarta Univ. Gadjah Mada, 2010 .

[8] J. E. Anderson, Cases in public policy-making. Holt McDougal, 1982.

[9] J. E. Anderson, Public policymaking. Cengage Learning, 2014. 